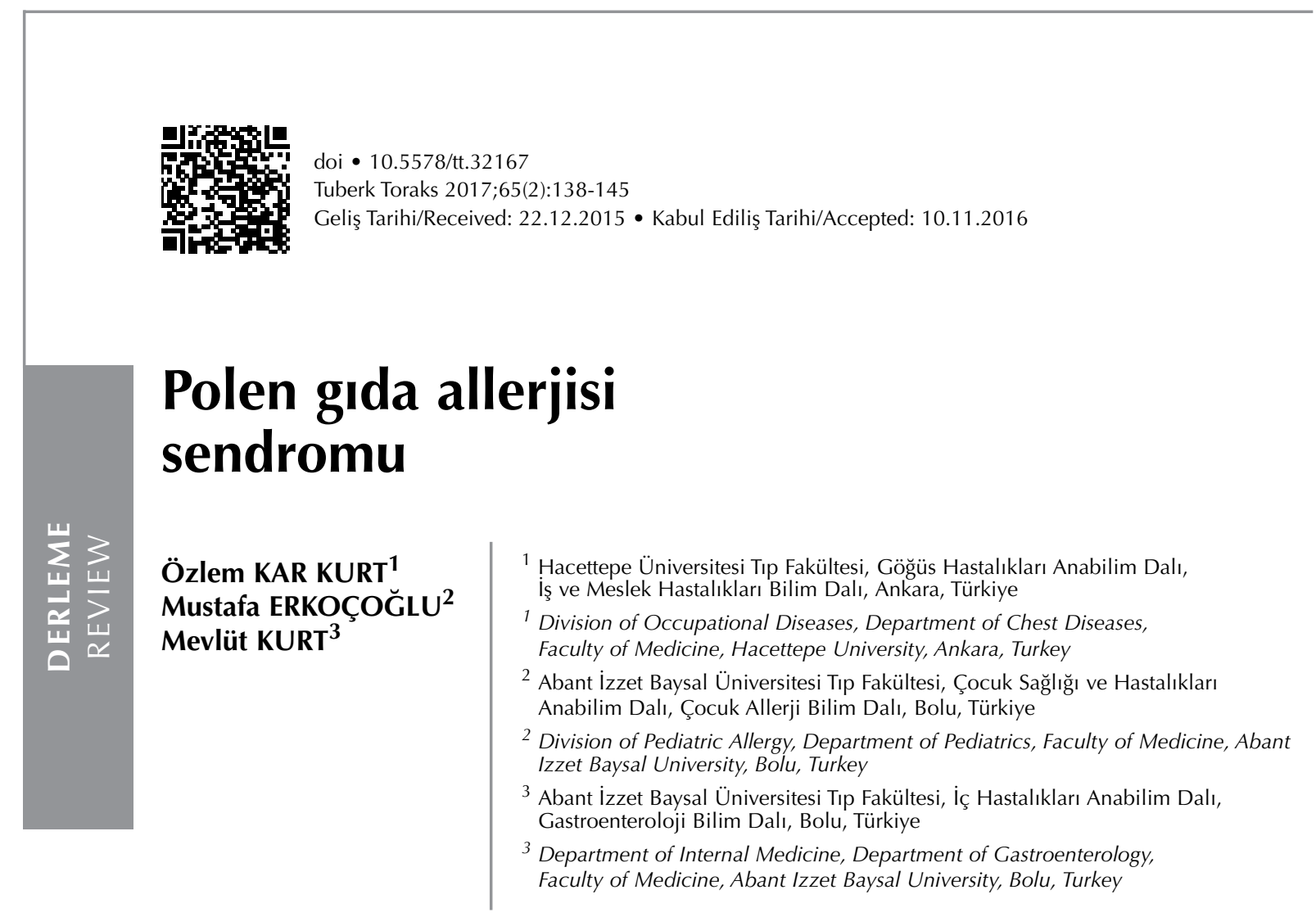

ÖZET

Polen gıda allerjisi sendromu

Polen gıda allerjisi sendromu, bir aeroallerjen ve bir bitki-türevi antijeni arasında, IgE antikorlarının aracılık ettiği tip I çapraz reaksiyondur. Esas semptomlar, sistemik semptomlar olmaksızın, tipik olarak dudak veya ağızda uyuşma, dudak, dil, damak ve farinkste kaşıntı, karıncalanma ve şişme gibi lokalize oral semptomlardan oluşur. Mevsimsel allerjik rinit, astım ya da her ikisinin bulunduğu hastalarda daha sık görülmektedir. Çoğu hastada hafif semptomlar olması, gıdalardan kaçınılması ile düzelmesi nedeniyle gerçek sıklığı bilinmemektedir. Bu derlemede polen gıda allerjisi sendromunun özellikleri ile tanı ve tedavi yaklaşımlarını mevcut literatürler eşliğinde tartışmayı amaçladık.

Anahtar kelimeler: Polen gıda allerjisi sendromu, tanı, tedavi

\title{
SUMMARY
}

\section{Pollen food allergy syndrome}

Pollen food allergy syndrome, is a type I cross-reaction mediated by IgE antibodies between an aeroallergen and a plant-derived antigen. Main symptoms are typically consist of localized oral symptoms such as numbness of the lip or mouth, itching, tingling and swelling of lips, tongue, palate and pharynx without systemic symptoms. Patients with seasonal allergic rhinitis, asthma or both more frequently experience pollen food allergy syndrome. Because most patients have mild symptoms and the improvement by avoiding food, the true incidence is unknown. In this review, we aimed to discuss characteristics, diagnosis and treatment of pollen food allergy syndrome according to existing literature.

Key words: Pollen food allergy syndrome, diagnosis, treatment

\section{Yazışma Adresi (Address for Correspondence)}

\section{Dr. Özlem KAR KURT}

Hacettepe Üniversitesi Tıp Fakültesi, Gögüus Hastalıkları Anabilim Dalı, iş ve Meslek Hastalıkları Bilim Dalı, ANKARA - TURKEY

e-mail: aghhozlem@yahoo.com 
Oral allerji sendromu, besin allerjisinin sık görülen bir formu olup daha çok erişkin yaş grubunda görülmektedir. ilk kez Tuft ve Blumstein tarafından gözlemlediği gibi allerjik rinit öyküsü olan hastaların çiğ meyve yedikten sonra ağızda kaşıntı, oral mukozada şişme gibi bulgularla prezente olmaktadır (1). Oral allerji sendromu terimi ilk kez 1987 yılında, Amlot ve arkadaşları tarafından, sadece orofaringeal allerji belirtileri olan atopi hastaları ile oral semptomlar, kusma, ishal, anjiyo ödem ve anafilaksi gibi sistemik semptomlara ilerleyenleri karşılaştırdıkları bir çalışmada kullanılmıştır (2). Daha sonra Valenta ve Kraft, polen gıda allerjisi sendromu (PGAS) terimini önermişlerdir ve günümüzde yaygın olarak bu terim kullanılmaktadır (3). PGAS, bir aeroallerjen ve bir bitkitürevi antijeni arasındaki, başta IgE aracılı tip I hipersensitivite reaksiyonu olmak üzere çeşitli mekanizmalar ile açıklanmaya çalışılan, çapraz reaksiyondur. PGAS çocukluk dönemi veya erişkin çağda ortaya çıkabilir. Sıklığı tam olarak bilinmemekle birlikte, erişkinlerdeki en sık besin allerjisi olduğunu söylemek mümkündür. Allerjik rinitin prevalansının fazla olduğu ülkelerde sıklığı artar. Orta Avrupa'da yapılan bir çalışmada PGAS'ın genel popülasyondaki sıklığının yaklaşık \%5 olduğu düşünülmektedir (4). Danimarka'da 1272 genç erişkinin dahil edildiği bir çalışmada katılımcıların \%17'sinde PGAS semptomlarının olduğu görülmüştür (5). Çocuklarda yapılan bir çalışmada genel çocuk popülasyonundaki sıklığı \%4.9 saptanırken, ağır allerjik riniti olan çocuklarda yapılan başka çalışmada, katılımcıların \%93'ünün PGAS semptomları gösterdiği görülmüştür $(6,7)$.

Genellikle hastalarda ilk önce polen allerjisi ve allerjik rinit (AR) ortaya çıkar ve allerjik rinitin şiddetinin artması ile birlikte PGAS gelişir. Ancak bazı olgularda belirgin AR olmaksızın PGAS ilk bulgu olabilir. Semptomlar her zaman görülsede en sık polen sezonunda gelişmektedir. Klinik bulgulara bakıldığında, hastaların çoğunda sistemik semptomlar olmaksızın, dudak veya ağızda uyuşma, dudak, dil, damak ve farinkste kaşıntı, karıncalanma ve şişme gibi lokalize oral semptomlar görülür (Hastaların \%2-10'unda ise rinit, konjunktivit, yüzde kızarma, bronşiyal astım, boğazda sıkışma hissi, yaygın ürtiker ve anafilaksi gibi sistemik semptomlar görülebilir). Tipik bulguları olmamakla birlikte, nadiren oral mukozada vezikül veya blister gelişebilir. Gastrointestinal sistem belirtileri karın ağrısı, bulantı, kusma ve ishal daha az görülür ve genellikle fazla miktarda yiyecek tüketildiğinde olur. Bu semptomlar genellikle meyve ve/veya sebze tüketildikten kısa süre sonra (5-10 dakika) ortaya çıkar ve kendi kendini sınırlayarak birkaç saniye ile birkaç dakika içinde sonlanır (8). Fizik muayenede dil şişmesi, uvular ödem, dudaklarda kızarıklık ve şişme, perioral ürtikeryal erüpsiyon, yüz ve periorbital ödem görülebilir. PGAS belirtileri sadece taze gıda alımından sonra olur, kaynatılmış, kimyasal olarak işlenmiş veya dondurulmuş gıdalar inek sütü, yumurta veya deniz ürünleri gibi bitki dışındaki gıdalar PGAS'a neden olmaz.

Neden bazı AR'lı hastalarda PGAS gelişirken, bazılarında gelişmediği tam olarak açıklanamamakla birlikte, PGAS için çeşitli risk faktörleri tanımlanmıştır. Polen duyarlıığı (özellikle huş ağacı) olanlarda PGAS daha sık iken; semptomatik polen allerjisi olan hastalarda (rinit, konjunktivit veya solunum semptomları), sadece polen duyarlıı̆̆g olup asemptomatik olan olgulara göre PGAS riski belirgin artmıştır (9). Yaş arttıkça PGAS sıklığı artar iken, kadınlarda çoklu polen duyarlanması olanlarda, ağır $A R^{\prime} ı$ olan ve polen spesifik IgE düzeyi yüksek olan olgularda PGAS riski artmaktadır (10). PGAS ile ilişkili en sık polenler; Orta ve Kuzey Avrupa'da, ot (Dactylis glomerata ve Phleum pretense) ve zaylan (Ambrosia elatior) Akdeniz ülkelerinde ise, ot, zaylan ve yapışkanotu polenleridir (Parietaria officinalis) (11). Duyarlı kişilerde, kayısı, mercimek, şeftali, domates gibi bazı gıdaların tüketiminin tipik PGAS'tan sistemik hastalığa ilerleme riski yüksektir (12).

Polen-spesifik IgE antikorları aynı epitopları paylaşan homolog besin allerjenlerini tanıyabilir. Besin allerjenleri mukozal mast hücrelerinin ve bazofillerin yüzeyindeki polen spesifik IgE'ye bağlanır ve PGAS ile sonuçlanan lokalize histamin salınmasını tetikler (13). Birçok bitki, patojen istilasına karşı korunmak için patojen-ilişkili (PR) proteinleri geliştirmiştir (13). PR proteinleri fizyolojik özelliklerindeki benzerliklere, biyolojik aktivite ve aminoasit sekansına dayalı olarak 17 aile halinde sınıflandırılmıştır (14). Ribozom inaktive edici proteinler (PR-10), lipid transfer proteinleri (LTP) (PR-14) ve thaumatin benzeri proteinler (PR-5), çeşitli meyve ve sebzelerde bulunan proteinler ile önemli bir homoloji paylaşmaktadır (Tablo 1).

Ana huş allerjeni olan Bet $v$ 1, PR-10 ailesinin bir üyesidir. Isıya ve sindirim enzimlerine duyarlı olup, yapısı kolayca bozulur. Genellikle sistemik olmadan oral kavite semptomlarına neden olur. Huş, çeşitli meyve ve sebzeye karşı aşırı duyarlılık ile ilişkili ilk polen allerjilerinden birisidir (15). Bet v 1 ile homolog 
Tablo 1. Spesifik meyveler, sebzeler, sert kabuklu yemişler, baharatlar, çiçekler ile spesifik aeroallerjenlerin ilişkisi (45)

Huş poleni Antep fıstığı (Pistacia vera; Pistachio nut), Armut (Pyrus communis; Pear), Badem (Amygdalus communis; Almond)*, Ceviz (Juglans regia; Walnut), Elma (Malus domestica;Apple), Erik (Prunus domestica; Plum)*, Fındık (Corylus avellana; Hazelnut), Fıstık (Arachis hypogaea; Peanut), Havuç (Daucus carota; Carrot)*, Hindiba (Taraxacum vulgare; Dandelion), Hurma (Phoenix canariensis; Date), Ispanak (Spinach; Spinachia oleracea), İncir (Ficus carica; Fig), Jackfruit (Artocarpus heterophyllus), Kavun (Cucumis melo; Melon), Kayısı (Prunus armeniaca; Apricot)*, Kereviz (Apium graveolens; Celery)*, Kestane (Castanea sativa; Sweet chestnut), Kiraz (Prunus avium; Cherry)*, Kivi (Actinidia deliciosa; Kiwi), Maydanoz (Petroselinum crispum; Parsley), Patates (Solanum tuberosum; Potato), Rezene (Foeniculum vulgare; Fennel)*, Soya (Glycine max; Soybean), Şeftali (Prunus persica; Peach)*, Üzüm (Vitis vinifera; Grapes), Havuç (Daucus carota; Carrot)

Zaylan Biber (Pepper), Havuç (Daucus carota; Carrot)*, Kabak (Brassica oleracea; Cabbage), Kara hindiba (Taraxacum vulgare; Dandelion), Karpuz (Citrullus lanatus; Watermelon), Kavun (Cucumis melo; Melon), Kereviz (Apium graveolens; Celery)*, Kişniş (Coriandrum sativum; Coriander), Kivi (Actinidia deliciosa; Kiwi), Muz (Musa acuminata; Banana), Papatya (Chrysanthemum leucanthemum; Marguerite), Rezene (Foeniculum vulgare; Fennel)*, Salatalık (Cucumis sativus; Cucumber), Şeftali (Prunus persica; Peach)*

Pelin Anason (Pimpinella anisum; Anise), Avokado (Persea americana; Avocado), Ayçiçeği (Helianthus annuus; Sunflower), Biber (Piper nigrum; Pepper), Dereotu (Anethum graveolens; Dill), Elma (Malus domestica; Apple), Hardal*, Havuç (Daucus carota; Carrot)*, Karpuz (Citrullus lanatus; Watermelon), Kereviz (Apium graveolens; Celery)*, Kimyon tohumu (fructus cumini; Cummin), Kişniş (Coriandrum sativum; Coriander), Mango, Maydanoz (Petroselinum crispum; Parsley), Papatya (Chrysanthemum leucanthemum; Marguerite), Rezene (Foeniculum vulgare; Fennel)*, Şeftali (Prunus persica; Peach)*

Ot poleni $\quad$ Antep fıstığı (Pistacia vera; Pistachio nut), Domates (Solanum lycopersicum; Tomato)*, Elma (Malus domestica; Apple), Havuç (Daucus carota; Carrot)*, (Phoenix canariensis; Date), (Ficus carica; Fig), (Citrullus lanatus; Watermelon), Kavun (Cucumis melo; Melon), Kereviz (Apium graveolens; Celery)*, Kestane (Castanea sativa; Sweet chestnut), Kivi (Actinidia deliciosa; Kiwi), Papatya (Chrysanthemum leucanthemum; Marguerite), Patlıcan, Şeftali (Prunus persica; Peach)*, Üzüm (Vitis vinifera; Grapes)

* Sistemik reaksiyonlar için risk oluştururlar.

proteinlere sahip sebze ve meyveler şunlardır; elma, kiraz, kayısı, armut, şeftali, fındık, kereviz, havuç, maydanoz, patates (13) (Tablo 2). Huş ağacına duyarlanması olan bireylerde, bu gıdaların tüketimi PGAS belirtilerine yol açabilir. Hemen hemen tüm huş poleni allerjisi hastalar Bet $v 1^{\prime} \mathrm{e}$ duyarlı olup, bu hastalarda diğer bitkiler ile çapraz reaksiyona bağlı PGAS riski vardır. Allerjen spesifik IgE varlığı klinik semptomatik allerjiyi tahmin ettirmez. Çünkü huş duyarlı hastalarda klinik olarak anlamlı gıda allerjisine katkıda bulunan faktörler büyük ölçüde bilinmemektedir. Bet $v$ 1-ilişkili besin allerjisi ve Ig düzeylerinde değişim arasında anlamlı bir ilişki saptanmamıştır (16). Gly $\mathrm{m} 4$ soya ürünlerinde tipik olarak bulunan bir antijendir, ancak PGAS yanı sıra anjiyoödem, dispne ve ürtikere yol açabilir (17). Allerjen spesifik IgE düzeyi bir belirteç olarak kullanılabilir (18). PGAS dışında, huş ağacı polenine duyarlı olan atopik dermatit hastalarında, bu gıdaların tüketiminden sonra egzemalarında şiddetlenme meydana gelebildiği gözlenmiştir (19).

Profilinler, panallerjen veya her yerde olan proteinler olup özellikle allerjik rinit ile ilgili olmayan polen, lateks ve bitki besin allerjisi sendromlarına neden olabilir. Genellikle ısı ve enzimatik yollarla kolayca denatüre oldukları için hafif veya inkomplet gıda allerjilerine yol açtığı düşünülmektedir (20).

Lipid transfer proteinleri (LTP), PR-14 ailesini oluşturur ve domates, şeftali, elma, kayısı, erik, kiraz, badem, üzümde bulunabilir (Tablo 2). LTP, huş veya polen allerjisi olmayan hastalarda elma ve şeftali tüketiminin tetiklediği PGAS'tan sorumlu çapraz reaksiyon yapan antijenlerdir (13). PGAS'a neden olan en sık allerjenlerin aksine, ısıya dayanıklı ve sindirim enzimlerine dirençli üç boyutlu yapıya sahiptir. Bu yapı, sadece ağız boşluğu ve alt gastrointestinal sistemde PGAS'a neden olan bir allerjen olarak değil, aynı zamanda, bağırsak duyarlanması ile klasik sınıf bir gıda allerjeni olarak hareket etmesine izin verir. Dayanıklılığı, allerjenin immünojenik ve allerjenik yapıda gastrointestinal sisteme ulaşmasını, duyarlanmaya ve sistemik semptomların oluşmasını sağlar. Sonuç olarak, bu protein ailesi ürtiker, anjiyoödem, dispne ve anafilaksi gibi ciddi sistemik reaksiyonlara neden olması daha olasıdır $(13,17,21)$. Pelin poleni LTP Art v 3, şeftali LTP Pru p 3 ile çapraz reaksiyon göstererek, pelin/şeftali ilişkili allerjiye neden olur (Tablo 3). 
Tablo 2. Bet v 1 ile homolog proteinlere sahip gıda örnekleri

\begin{tabular}{|c|c|c|c|c|c|}
\hline $\begin{array}{l}\text { Ilgili allerjen } \\
\text { örnekleri }\end{array}$ & & & $\begin{array}{c}\text { PR-10 proteinleri, } \\
\text { Bet v } 1 \text { homologlar } \\
\text { (ISI ve sindirime duyarlı) }\end{array}$ & $\begin{array}{c}\text { Profilinler, } \\
\text { Bet v } 2 \text { homologlar }\end{array}$ & LTP \\
\hline Huş & Betula verrucosa & Common silver birch & Bet $v 1$ & Bet $\vee 2$ & \\
\hline Kızılağaç & Alnus glutinosa & Alder & rAln g 1 & & \\
\hline Elma & Malus domestica & Apple & Mal d 1 & Mal d 4 & Mal d 3 \\
\hline Şeftali & Prunus persica & Peach & Prup 1 & Prup 4 & Prup 3 \\
\hline Kereviz & Apium graveolens & Celery & Api g 1 & Api g 4 & Api g 2 \\
\hline Havuç & Daucus carota & Carrot & Dau c 1 & Dau c 4 & \\
\hline Soya & Glycine max & Soybean & Gly m 4 & & \\
\hline Kiraz & Prunus avium & Cherry & Pru av 1 & & \\
\hline Kayısı & Prunus armeniaca & Apricot & Pru ar 1 & & \\
\hline Kivi & Actinidia deliciosa & Kiwi & Act d 8 & Act d 9 & \\
\hline Armut & Pyrus communis & Pear & Pyr c 1 & & \\
\hline Fındık & Corylus avellana & Hazelnut & Cor a 1 & Cor a 2 & Cor a 8 \\
\hline Kestane & Castanea sativa & Sweet chestnut & Cas s 1 & & \\
\hline Fistık & Arachis hypogaea & Peanut & Ara h 8 & & \\
\hline Domates & Solanum lycopersicum & Tomato & Sola 14 & & \\
\hline Zeytin & Olea europaea & Olive & & Ole e 2 & Ole e 7 \\
\hline Sirken (kazayağı) & Chenopodium album & Goosefoot & & Che a 2 & \\
\hline Pelin & Artemisia vulgaris & Mugwort & & Art $\vee 4$ & Art $\vee 3$ \\
\hline Zaylan & Ambrosia artemisiifolia & Ragweed & & Amb a 8 & Amb a 6 \\
\hline Kavun & Cucumis melo & Melon & & Cuc m 2 & Cuc m LTP \\
\hline Muz & Musa acuminata & Banana & & Mus a 1 & Mus a 3 \\
\hline Beyaz hardal & Sinapis alba & White mustard & & Sin a 4 & Sin a 3 \\
\hline Lateks & Hevea brasiliensis & Latex & & Hev b 8 & \\
\hline Lahana & Brassica oleracea & Cabbage & & & Bra o 3 \\
\hline Üzüm & Vitis vinifera & Grape & & & Vit $\vee 1$ \\
\hline Ceviz & Juglans regia & Walnut & & & Jug r 3 \\
\hline Çınar & Platanus acerifolia & Plane tree & & & Pla a 3 \\
\hline
\end{tabular}

Tablo 3. Sendrom ve ilgili allerjen bileşenleri ilişkisi (46)

\begin{tabular}{|ll|}
\hline Sendrom veya ilişki & ilgili allerjen bileşenleri (allerjen kaynaklar) \\
\hline Huş-elma sendromu & Bet v 1 homologu Mal d 1 \\
Selvi-şeftali sendromu & Pru p 3 LTP \\
Kereviz-pelin-baharat sendromu & Art v 4 profilin, Api g 5 homologu Art v 60 kDa \\
Pelin-şeftali ilişkisi & Pru p 3 LTP, Art v 3 LTP, Art v 4 profilin \\
Pelin-papatya ilişkisi & Art v 1 defensin (olası aday) \\
Pelin-hardal sendromu & Art v 3 LTP, Art v 4 profilin, Art v 60 kDa(olası aday) \\
Zaylan-kavun-muz ilişkisi & Amb a 6 LTP, Amb a 8 profilin (olası aday) \\
Kazayağı-kavun ilişkisi & Che a 2 profilin (olası aday) \\
\hline & \\
\hline
\end{tabular}

Ayırıcı tanıda; yanan ağız sendromu, anjioyödem, allerjik rinit ve diğer oral hastalıklar düşünülebilir. Gıdaların yanı sıra, PGAS ayrıca temel kaynağı sebze olan lateks aşırı duyarlılığı olan hastalarda ortaya çıkabilir (22). Bu reaksiyon, çapraz reaktif proteinleri denatüre etmek için, çiğ sebze ve meyve pişirme ile azalabilir veya önlenebilir. Çapraz reaksiyon gösteren epitoplar immünoterapi veya allerji teşhisinde yardımcı olabilirler. 
Lateks ve çeşitli meyveler arasında önemli çapraz reaktivite gösterilmiş olup, lateks allerjisi olan yetişkinlerin \%88'ine kadarında bitki spesifik IgE rapor edilmiştir. Ancak, bunların önemli bir kısmında klinik bulgu ortaya çıkmamaktadır. Meyve allerjisi olan 57 bireyin dahil edildiği bir çalışmada \%86'sı lateks duyarlı saptanırken, katılımcıların sadece $\% 10.5^{\prime}$ inde (57 kişiden 6'sı) klinik açıdan anlamlı lateks allerjisi olduğu görülmüştür (22). Almanya'da yapılan bir çalışmada lateks allerjisi olan 136 yetişkinin $\% 42.5$ 'inde meyve yenmesi ile semptomlar bildirilmiştir, ancak semptomu olanların sadece \%32.1 meyve-spesifik IgE saptanabilmiştir (23). Lateksmeyve sendromu sadece lokalize oral belirtilerle kendini gösterebilir ya da sistemik reaksiyonları tetikleyebilir (24).

\section{TANI}

\section{Lokalize, orofarengeal belirtiler}

- Dudak/ağız şişliği

- Dudak/ağız/boğaz kaşıntısı

- Larinks ödemi

\section{Sistemik belirtiler}

- Deri: ürtiker, anjiyoödem

- Oküler: konjunktivit

- Üst solunum yolu: burun akıntısı, tıkanıklık, hapşırık

- Alt solunum yolu: hışıltı, ölsürük, dispne

- Gastrointestinal: karın ağrısı, kramplar, mide bulantısı, kusma, ishal

\section{Anafilaksi}

Lokal, sistemik belirtiler ile anafilaksi gelişen hastalarda PGAS ön tanılar arasında yer almalıdır. Semptomların şiddetinde polen sezonunda artış olabilir. Bunun, mevsim içerisinde polen maruziyeti sonucu huş ağacı poleni (Bet $v 1$ ve 2)'e özgü IgE düzeyinde artışa bağlı olduğuna inanılmaktadır (25). Klasik gıda allerjisi tanısı için altın standart şüpheli gıdaların artan dozlarda hastaya verildiği ve hastanın olası reaksiyon açısından gözlemlendiği besin provakasyon testidir (26). Ancak bu test zaman alıcıdır, sonuç test edilen gıdalara bağlı olarak değişebilir ve ciddi sistemik reaksiyon riski taşımaktadır.

Deri prik testi: Uygulaması kolay ve ekonomik olan ve duyarlanmayı göstermede kullanılan en sık testtir. Ancak; tüm allerjenleri içeren ticari materyal bulunmayabilir, işlem sırasında ısı duyarlı proteinler bozu- labilir ve yanlış negatif sonuç verebilir. Ayrıca deri prik testinin pozitif olması her zaman klinik bulgu olacağı anlamına gelmez. Özellikle meyve ve sebzelerde ticari formların stabilizasyon probleminden dolayı, direkt olarak şüpheli allerjenin kendisi taze olarak ("prick to prick") testte kullanılabilmektedir.

Spesifik IgE testi: Besin ve polenlere spesifik IgE düzeyi in vitro olarak ölçmek mümkündür. Tıpkı deri prik testlerinde olduğu gibi yanlış negatif sonuçlar olabileceği gibi, pozitif sonuç klinik bulgu olacağı anlamına gelmez. Örneğin, kereviz spesifik IgE düzeyi ile klinik şiddet arasında ilişki saptanmamıştır. Bazı çalışmalarda şeftali spesifik IgE düzeyleri ile klinik reaksiyon arasında ilişki saptanırken bu ilişkiyi saptamayan çalışmalar da bulunmaktadır (27-29).

Bazofil aktivasyon testi: Allerjenle inkübasyon sonrası aktive bazofiller tarafından CD63 ve CD203c eksprese edilmesi ve bunun akım sitometride gösterilmesi esasına dayanır. Testin zor olması ve yapılan merkeze göre standartın değişmesi nedeniyle sadece çalışma amaçlı kullanılmaktadır.

CAST-ELISA testi: Hücresel antijen stimülasyon test: Spesifik allerjen stimülasyonu sonrası duyarlı lökositlerden salınan sülfidolökotrienşerin ELISA ile ölçülmesidir. > $200 \mathrm{pg} / \mathrm{mL}$ pozitiftir. Yöntemin zor ve pahalı olması nedeniyle yaygın olarak kullanılmamaktadır.

\section{TEDAVi}

Botanik ailesinin bir üyesine karşı oluşan klinik belirtiler, o botanik ailesindeki tüm gıdalara oluşacağı anlamına gelmez. Allerjik reaksiyonun şiddeti farklı meyve çeşitleri arasında değişebilir. Düşük allerjik bitki-meyve çeşitlerinin seçimiyle bazı belirtiler azaltılabilir. Allerjen dağılımı meyvenin tüm kısımlarında tekdüze değildir. Örneğin, LTP iç kısmı ile karşılaştırıldığında elma ve şeftalinin kabuğunda çok daha yüksek miktarda bulunur (30). Küçük bir çalışmada, elma ve armut allerjisi olan bireylerin \%40' । meyvenin etli kısmını (kabuksuz kısmı) tolere ederken, bütün meyve yenmesi durumunda belirtiler oluşmuştur (31). Bir meyve veya sebze ile PGAS bulguları ortaya çıkan bireylerde, tüm botanik ailelerin yasaklanması gerekli değildir ve bu durum etkilenen bireyler için aşırı kısıtlayıcı olacaktır.

Şeftali allerjisi olan İspanyol çocukların dahil edildiği bir çalışmada \%28 epinefrin tedavisi gerektiren şiddetli reaksiyonlar geçirdikleri bildirilmiştir (32). Sistemik reaksiyon riskinin arttığı durumlar; 
- Gıdanın pişmiş formlarına reaksiyon öyküsü,

- Gıda ile sistemik reaksiyon öyküsü,

- Ticari gida ekstresi pozitif deri prik test,

- Polen duyarlılığıve LTP için duyarlıığın olmaması.

Ayrıca, eşlik eden atopik hastalıklar ve ilaç kullanımı düşünülmesi gereken önemli ayrıntılardır. Örneğin, allerjik rinit nedeniyle günlük antihistaminik alan bireylerin erken hafif PGAS belirtileri fark edilmeyebilir, tetikleyen gıdaların tüketiminin artmasına neden olur ve sistemik belirtilerin oluşma riski artar (33).

Eğitim, kaçınma ve gıdaların pişirilmesi, lokal orofarinjiyal reaksiyonların gelişmesini engelleyebilir. Lokal reaksiyon gelişen olgularda antihistaminik tedavisi ve nadir de olsa anafilaksi gelişmesi durumunda epinefrin enjeksiyonu önerilir. Isıya duyarlı proteinler semptomları oluşturuyorsa, meyve ve sebzeleri ısıtma veya pişirme semptom oluşmasını önleyebilir (Tablo 4). Tipik pişmemiş formda yenen gıdalar (örn. elma) için, meyve bütünlüğünü korunarak, mikrodalgada kısa ısıtma yeterince Bet $v$ 1-homologunu denatüre edebilir. Ayrıca elmanın sık ve düzenli tüketimi PGAS semptomlarında azalma ile ilişkili bulunmuştur (34). Kiviyi $100^{\circ} \mathrm{C}^{\prime}$ de 5 dakika buharda pişirmenin allerjik bireylerde toleransı artırdığı gösterilmiştir (35). Yiyeceğin soyulması yeterli korunma sağlamayabilir. iç kısmı allerjen içerebilir veya tutma sırasında kontamine olabilir. Her ne kadar ısıtılmanın veya pişirilmenin faydalı olduğu görülse de; atopik dermatitli hastalarda termal işlenmiş meyve ve sebze tüketimi geç, T-hücre-aracılı reaksiyona ve egzema kötüleşmesine neden olabilmektedir (36). LTP molekülünün stabilize disülfür bağı yapısı, bu proteinleri ISI denatürasyonuna son derece dirençli yapar (37). Bazı gıdalarda ısıya maruziyet gıdanın allerjenitesinde artma ya da azalmalara sebep olabilir. Örneğin yapılan bir çalışmada kavrulmuş fıstığın allerjenitesinin (Ara $h 1$ ve 2) çiğ fıstığa göre belirgin olarak arttığı gösterilirken (Ara h 1 ve 2) başka bir çalışmada

\begin{tabular}{l}
$\begin{array}{l}\text { Tablo 4. PGAS'a neden olabilen ısı duyarlı ve ısı kararlı çiğ } \\
\text { gıda allerjenleri }\end{array}$ \\
\begin{tabular}{|ll|}
\hline $\begin{array}{l}\text { Isı duyarlı } \\
\text { allerjenler* }\end{array}$ & kivi, incir, kuşkonmaz, soya, havuç** \\
$\begin{array}{l}\text { Isıya dayanıklı } \\
\text { allerjenler }\end{array}$ & $\begin{array}{l}\text { Şeftali, portakal, kiraz, kavun, ceviz, } \\
\text { pekan, antep fıstığı, papatya, buğday, } \\
\text { arpa, pirinç }\end{array}$ \\
$\begin{array}{l}\text { Isı duyarlı } \\
\text { ve dayanıklı } \\
\text { allerjenler }\end{array}$ & Elma, fındık, fıstık, domates, kereviz \\
\hline
\end{tabular} \\
\hline
\end{tabular}

ise, kavrulmuş yer fıstığının 15 ve 30 dakika süre ile $138^{\circ} \mathrm{C}$ sıcaklıkta otoklavlandığında IgE bağlayıcı fıstık allerjenlerin kapasitesinde önemli bir azalma elde edilmiştir $(38,39)$.

Buna ek olarak, PGAS benzeri semptomları olan ancak aeroallerjen duyarlılığı olmayan hastaların bir kısmında, elmada bir LTP olan Mal d 3 IgE reaktivitesinin $90^{\circ} \mathrm{C}^{\prime}$ de 20 dakika ısıtıılmasına rağmen değişmeden kaldığı gösterilmiştir (40). Benzer şekilde, kirazdaki bir LTP olan Pru av 3 ün Isı işlemden sonra çok daha yüksek bir allerji potansiyelini koruduğu gösterilmiş̧ir (41). Bu nedenle, bu hasta alt grubunda, ısıtma profilaksi için etkisizdir. Buna ek olarak, daha önce de ifade ettiğimiz gibi huş ağacı poleni allerjisi ve atopik dermatiti olan hastalarının huş ile çapraz reaksiyon veren meyvelerin pişmiş olarak tüketimi egzamayı alevlendirmektedir (36). Huş ağacı polen allerjisi ve atopik dermatit olan hastalarda, pişmiş huş ilgili gıda allerjenleri IgE bağımlı olmayan bir hücresel cevap oluşturur. Pişirilme sonrası IgE bağlama kapasitesini kaybetseler bile, T-hücrelerini aktive etme yeteneklerini korurlar ve atopik dermatiti tetiklerler (36).

Huş ağacı poleni ile immünoterapinin allerjik rinokonjunktivit ile birlikte PGAS bulunan hastalarda etkili olduğu gösterilmiştir (42). Ancak epitoplar arasında benzerlik sınırlı olduğu için immünoterapi sonrası PGAS'ta kesin olarak azalma olmayabilir. Huş ağacı poleni spesifik immünoterapi (SiT) sonrası elmaya bağlı PGAS'lı hastaların \%84'ünde belirtiler kaybolmuştur (43). Ancak SiT sonrası PGAS gelişen olgular da bildirilmiştir (44). Meyve ve sebzeler, birden fazla allerjik protein içerebilir ve bu proteinlere bireysel sensitizasyon profilleri, coğrafi bölge, beslenme alışkanlıkları ve polinoz ise bağlı değiş̧ebilir (45).

Sonuç olarak, PGAS özelikle erişkin yaş grubunda olmak üzere polen duyarlanması olan allerjik rinitli hastalarda sıklıkla gözlenmektedir. Polen ile çeşitli meyve ve sebzelere ait antijenlerin çapraz reaksiyon vermesi sonucu olguların çoğunda lokalize orofarengeal semptomlara neden olurken, nadiren sistemik reaksiyonlar da ortaya çıkabilmektedir. Temel tedavi, semptoma neden olan besinin diyetten çıkarılmasıdır. Gıdaların ısıtılması bazı allerjenlerde klinik fayda sağlarken bazı allerjenlerde antijeniteyi artırabilmektedir. Bu nedenle tedavide PGAS'a neden olan besinin özelliğine göre seçim yapmak uygun olacaktır. 


\section{KAYNAKLAR}

1. Tuft L, Blumstein GI. Studies in food allergy: II. Sensitization to fresh fruits: clinical and experimental observations. I Allergy 1942;13:574-82.

2. Amlot PL, Kemeny DM, Zachary C, Parkes P, Lessof $M H$. Oral allergy syndrome (OAS): symptoms of IgE-mediated hypersensitivity to foods. Clin Allergy 1987;17:33-42.

3. Valenta $R$, Kraft $D$. Recombinant allergens for diagnosis and therapy of allergic diseases. Curr Opin Immunol 1995;7:7516.

4. Sicherer SH. Clinical implications of cross-reactive food allergens. J Allergy Clin Immunol 2001;108:881-90.

5. Osterballe M, Mortz CG, Hansen TK, Andersen KE, BindslevJensen $C$. The prevalence of food hypersensitivity in young adults. Pediatr Allergy Immunol 2009;20:686-92.

6. Brown CE, Katelaris CH. The prevalence of the oral allergy syndrome and pollen-food syndrome in an atopic paediatric population in south-west Sydney. I Paediatr Child Health 2014;50:795-800.

7. Moller C. Effect of pollen immunotherapy on food hypersensitivity in children with birch pollinosis. Ann Allergy 1989;62:343-5.

8. Ausucua M, Dublin I, Echebarria MA, Aguirre JM. Oral allergy syndrome (OAS). General and stomatological aspects. Med Oral Patol Oral Cir Bucal 2009;14:568-72.

9. Osterballe M, Hansen TK, Mortz CG, Bindslev-Jensen C. The clinical relevance of sensitization to pollen-related fruits and vegetables in unselected pollen-sensitized adults. Allergy 2005;60:218-25.

10. Ivkovic-Jurekovic I. Oral allergy syndrome in children. Int Dent J 2015;65:164-8.

11. Liccardi G, Russo M, Mistrello G, Falagiani P, D'Amato $M$, $D^{\prime} A m a t o$ G. Sensitization to pistachio is common in Parietaria allergy. Allergy 1999;54:643-5.

12. Ivicevic N, Roje Z, Kljajic Z, Bojic L, Kardum G, Omero L, et al. Prevalence and risk factors for developing oral allergy syndrome in adult patients with seasonal allergic rhinitis. Acta Clin Croat 2015;54:25-9.

13. Sloane D, Sheffer A. Oral allergy syndrome. Allergy Asthma Proc $2001 ; 22: 321-5$.

14. Sels J, Mathys J, De Coninck BM, Cammue BP, De Bolle MF. Plant pathogenesis-related (PR) proteins: a focus on $P R$ peptides. Plant Physiol Biochem 2008;46:941-50.

15. Hannuksela $M$, Lahti $A$. Immediate reactions to fruits and vegetables. Contact Dermatitis 1977;3:79-84.

16. Guhsl EE, Hofstetter G, Lengger N, Hemmer W, Ebner C, Froschl $R$, et al. IgE, IgG4 and IgA specific to Bet $v$ 1-related food allergens do not predict oral allergy syndrome. Allergy 2015;70:59-66.

17. Ma S, Sicherer SH, Nowak-Wegrzyn A. A survey on the management of pollen-food allergy syndrome in allergy practices. J Allergy Clin Immunol 2003;112:784-8.
18. Berneder $M$, Bublin $M$, Hoffmann-Sommergruber $K$, Hawranek T, Lang R. Allergen chip diagnosis for soy-allergic patients: Gly $m 4$ as a marker for severe food-allergic reactions to soy. Int Arch Allergy Immunol 2013;161:229-33.

19. Breuer K, Wulf A, Constien A, Tetau D, Kapp A, Werfel T. Birch pollen-related food as a provocation factor of allergic symptoms in children with atopic eczema/dermatitis syndrome. Allergy 2004;59:988-94.

20. Alvarado MI, Jimeno L, De La Torre F, Boissy P, Rivas B, Lazaro $M J$, et al. Profilin as a severe food allergen in allergic patients overexposed to grass pollen. Allergy 2014;69:1610-6.

21. Pascal M, Munoz-Cano $R$, Reina $Z$, Palacin A, Vilella $R$, Picado $C$, et al. Lipid transfer protein syndrome: clinical pattern, cofactor effect and profile of molecular sensitization to plant-foods and pollens. Clin Exp Allergy 2012;42:152939.

22. Garcia Ortiz JC, Moyano JC, Alvarez M, Bellido J. Latex allergy in fruit-allergic patients. Allergy 1998;53:532-6.

23. Brehler R, Theissen U, Mohr C, Luger T. "Latex-fruit syndrome": frequency of cross-reacting $\lg E$ antibodies. Allergy 1997;52:404-10.

24. Yagami T. Allergies to cross-reactive plant proteins. Latexfruit syndrome is comparable with pollen-food allergy syndrome. Int Arch Allergy Immunol 2002;128:271-9.

25. Magnusson J, Lin XP, Dahlman-Hoglund A, Hanson LL, Telemo $E$, Magnusson $O$, et al. Seasonal intestinal inflammation in patients with birch pollen allergy. J Allergy Clin Immunol 2003;112:45-50.

26. O'Keefe AW, De Schryver S, Mill J, Mill C, Dery A, BenShoshan M. Diagnosis and management of food allergies: new and emerging options: a systematic review. J Asthma Allergy 2014;7:141-64.

27. Rossi RE, Monasterolo G, Canonica GW, Passalacqua G. Systemic reactions to peach are associated with high levels of specific IgE to Pru p 3. Allergy 2009;64:1795-6.

28. Gaier S, Oberhuber C, Hemmer W, Radauer C, Rigby NM, Marsh JT, et al. Pru p 3 as a marker for symptom severity for patients with peach allergy in a birch pollen environment. J Allergy Clin Immunol 2009; 124:166-7.

29. Novembre E, Mori F, Contestabile S, Rossi ME, Pucci N. Correlation of anti-Pru p 3 lgE levels with severity of peach allergy reactions in children. Ann Allergy Asthma Immunol 2012;108:271-4.

30. Borges JP, Jauneau A, Brule C, Culerrier R, Barre A, Didier $A$, et al. The lipid transfer proteins (LTP) essentially concentrate in the skin of Rosaceae fruits as cell surface exposed allergens. Plant Physiol Biochem 2006;44:535-42.

31. Fernandez-Rivas $M$, Cuevas $M$. Peels of Rosaceae fruits have a higher allergenicity than pulps. Clin Exp Allergy 1999;29:1239-47.

32. Boyano-Martinez T, Pedrosa M, Belver T, Quirce S, GarciaAra C. Peach allergy in Spanish children: tolerance to the pulp and molecular sensitization profile. Pediatr Allergy Immunol 2013;24:168-72. 
33. Mari A, Ballmer-Weber BK, Vieths S. The oral allergy syndrome: improved diagnostic and treatment methods. Curr Opin Allergy Clin Immunol 2005;5:267-73.

34. Kopac P, Rudin M, Gentinetta T, Gerber R, Pichler C, Hausmann $O$, et al. Continuous apple consumption induces oral tolerance in birch-pollen-associated apple allergy. Allergy 2012;67:280-5.

35. Fiocchi A, Restani P, Bernardo L, Martelli A, Ballabio C, $D^{\prime}$ Auria $E$, et al. Tolerance of heat-treated kiwi by children with kiwifruit allergy. Pediatr Allergy Immunol 2004; 15:4548.

36. Bohle B, Zwolfer B, Heratizadeh A, Jahn-Schmid B, Antonia $Y D$, Alter $M$, et al. Cooking birch pollen-related food: divergent consequences for IgE- and $T$ cell-mediated reactivity in vitro and in vivo. I Allergy Clin Immunol 2006;118:242-9.

37. van Ree R. Clinical importance of non-specific lipid transfer proteins as food allergens. Biochem Soc Trans 2002;30(Pt 6):910-3.

38. Maleki SJ, Chung SY, Champagne ET, Raufman JP. The effects of roasting on the allergenic properties of peanut proteins. J Allergy Clin Immunol 2000;106:763-8.

39. Cabanillas B, Maleki SJ, Rodriguez J, Burbano C, Muzquiz $M$, Jimenez $M A$, et al. Heat and pressure treatments effects on peanut allergenicity. Food Chem 2012;132:360-6.

40. Sancho Al, Rigby NM, Zuidmeer L, Asero R, Mistrello G, Amato $S$, et al. The effect of thermal processing on the IgE reactivity of the non-specific lipid transfer protein from apple, Mal d 3. Allergy 2005;60:1262-8.
41. Scheurer S, Lauer I, Foetisch K, San Miguel Moncin M, Retzek M, Hartz C, et al. Strong allergenicity of Pru av 3, the lipid transfer protein from cherry, is related to high stability against thermal processing and digestion. I Allergy Clin Immunol 2004;114:900-7.

42. Hoiby AS, Strand V, Robinson DS, Sager A, Rak S. Efficacy, safety, and immunological effects of a 2-year immunotherapy with Depigoid birch pollen extract: a randomized, doubleblind, placebo-controlled study. Clin Exp Allergy 2010;40:1062-70.

43. Asero R. Effects of birch pollen-specific immunotherapy on apple allergy in birch pollen-hypersensitive patients. Clin Exp Allergy 1998;28:1368-73.

44. Ciprandi G. Onset of oral allergic syndrome during birch sublingual immunotherapy. Eur Ann Allergy Clin Immunol 2012;44:170-1.

45. Price A, Ramachandran S, Smith GP, Stevenson $M L$, Pomeranz MK, Cohen DE. Oral allergy syndrome (pollenfood allergy syndrome). Dermatitis 2015;26:78-88.

46. Popescu FD. Cross-reactivity between aeroallergens and food allergens. World J Methodol 2015;5:31-50. 